\title{
EXAMINATION OF HOW A SETTLEMENT ON THE GREAT PLAIN BECAME A TOWN, WITH A SPECIAL REGARD TO ITS PRESENT AND FUTURE
}

\author{
Dr. habil. Ph.D. Gál, József - Bódi Brigitta Mária ${ }^{2}$ - Nagy, Sándor Ph.D. student ${ }^{3}$ - Kovács, \\ Zoltán Ph.D. student ${ }^{4}$ \\ 'associate professor, University of Szeged, Faculty of Engineering, Szeged \\ ${ }^{2}$ engineer, University of Szeged, Faculty of Engineering, Szeged \\ ${ }^{3}$ assistant lecturer, University of Szeged, Faculty of Engineering, Szeged \\ ${ }^{4}$ titular associate professor, University of Szeged, Faculty of Engineering, Szeged
}

\begin{abstract}
SUMMARY
We are aiming to describe the process how Sándorfalva was declared a town, its economic, social, infrastructural conditions, its level and the course of development.

We are seeking answers to these questions: what possibilities, risks, weak and strong points does this settlement have? What is the future strategy of this town, and how does it intend to realize it? We have two important conclusions here. The first one is that it is the human factor which is in the centre of development, so we are emphasizing the importance of collaboration, the other one is the formation of competitiveness which can result in a town of European level.
\end{abstract}

\section{INTRODUCTION}

Rural development has brought about a certain kind of differentiation in our country. The development was concentrated on the bigger settlements, so the investors were hindered to get in touch with the villages. Urbanization was too slow, in 1981 the number of small towns was low, only $20-25$.

Settlements with the functions of small towns can be found mostly in the group of the approximately 600 so-called ,nagyközség" (means big village, but not a town yet), which is a large village constituting an administrative division in Hungary.

It is well-known which areas lack the towns in the country, which large villages can be improved to become urbanized small towns. It is expected to amplify the network of small towns and this way to decrease the amount of areas without towns. The main purpose is that the population of villages can find and use the urban institutions. within the distance of less than an hour in the whole country. (Perczel 1982)

When we are analyzing the process of how Sándorfalva was declared a town and its urbanization efforts, we are intending to show how it is possible to form a competitive, pleasant town due to its improvement.

\section{DESCRIPTION OF SÁNDORFALVA}

„...towns are the symbiosis of the past and future, thus they were the scenes of time and development in the past, and they remained so even today, so they are the evidence of continuity" (Granasztói 1984) The life of farms means everything for the older ones, their way of life cannot be changed. They have got used to the natural environment, they can stand the extreme weather. For them, work from the first glimmer of dawn till night is essential together with all the struggles. (Gálné 2010)

The past of Sándorfalva cannot be separated from the history of the village of Algyö. Foundation of the settlement is due to a sad catastrophe of flooding. Marquis Pallavicini, Sándor offered an area from his own estate to found a new settlement, and he got a part of the population of Algyő to settle down there. The Marquis gave not only the area but his name, too to the village. The village was inaugurated with all solemnity on 20 August, 1879. In 1882 the church, the village hall, the school and gendarme post were all constructed (Komor 1985). 
The marquis placed the residence of the estate to Sándorfalva. The population worked mostly in the estate as farm hands, servants and craftsmen.

Beside the old village of regular structure a new part has been built since 1950-60. The size of the settlement is around $56 \mathrm{~km} 2$, most of which $-9 / 10$ - belongs to the outskirts. Its population is Hungarian; the major part is Roman Catholic. $8 \%$ of the residence can be found in the outskirts.

In 1969 there was a big change in the settlement life when it became a „nagyközség” which generated improvement.

The infrastructural, service and supplying sectors started to improve from the 1970s. It had been a separated settlement for a long time since there was no road connection of good quality neither with Szeged nor with the international road only two kilometers away. The power supply was started in 1949, the drinking water supply was built in 1968, and from 1980 the streets are covered with solid surface, today more than $80 \%$ of the streets have solid surface. The piped gas supply was built between 1984-1988 more than 2500 residences were connected to it till 2005. In 1993 the telephone and cable television network was extended. 4 net-suppliers work in the settlement in 2005. The number of housing plots was five times more, regarding the state at the time of foundation, partly by dividing the earlier plots of 2000 $\mathrm{m} 2$, and partly by utilizing new areas, thus the inner area more than doubled. The centre of Sándorfalva has been under reconstruction since 2002 where you can find the large, shady Szabadság square with the Roman Catholic church erected to adore Virgin Mary. Busts to Petöfi Sándor and Arany, János can be found on the main square close to the Town Hall. The life of the „nagyközség” started to boom when the president declared it a town on 1 July, 2005.

\section{Picture 1. A modern bus station in Sándorfalva}

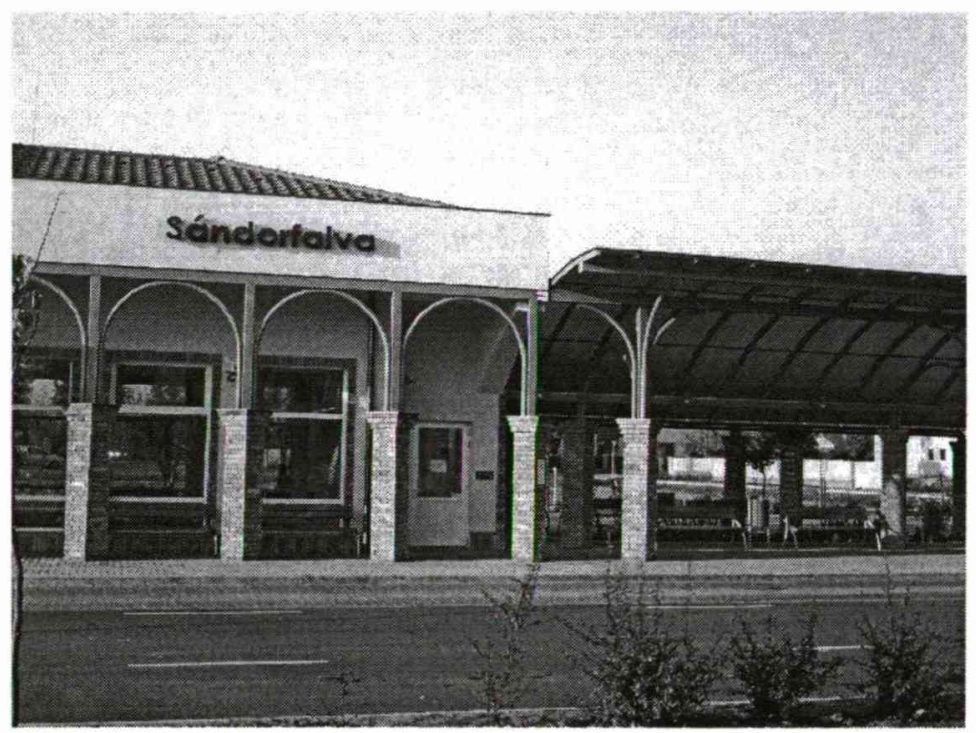

Source: the author's image, 2011

It obtained a new scope of tasks to represent the development of its catchment area. It set as an aim to reconstruct the community form. Let's examine the steps which affected this transformation. The attained situations were regarded as the conditions of further steps. People of Sándorfalva did not shape a dreamy town image considering the future. 
According to the new situation a bigger chance of acting, collaboration were provided for the population to improve the situation of people living there, so a rapprochement of townvillage can be formed continuously. The transportation is under improvement, a new bus station has been built. (Picture 1)

For a small town it is important to have a trustworthy institution which is supported by the community and which can get reputation from this support. The institutions of community inspire the social development; they are places where it is worth going to. All in all, they are aiming to create the rapprochement of the urban living conditions, the availability of the level of supply and the urban services which is in strong connection with the modern demands of a small town.

Development has transformed the outer look of the village. The main purpose was to form a small town which can fulfill the modern demands but, at the same time, it preserves its unique traditions and then it applies them consciously. The strong force of traditions, the rich historical heritage determines the tasks of the settlement. Besides, its structural conditions, the rare historical and aesthetical values of its buildings determine the direction and the way of development of Sándorfalva.

Today the settlement is not the exclusive place of the agricultural production. Electricity, an access road, comfortable houses, inner road network, system of telecommunication, health care, system of education and local administration are all present. Small and middle-sized industrial ventures are present, too, though in a smaller measure. It is a must to improve the shop network and other tasks of supply. It is necessary to utilize that small amount of money from different sources cleverly in order to make the settlement a significant regional centre.

It is worth making a matter of curiosity an attraction. It is necessary to organize programs to make a settlement attractive. People there are aiming to stay open to the world and not to feel they are just rural not forgetting their roots, the Pallavicini-heritage- where they come from which have always been a great treasure.

\section{THE TOWN AS THE RESULT OF THE PROCESS OF URBANIZATION}

In the Hungarian history the first towns - to 1867- were market-towns and free royal cities. Then a new category: the town with the municipal law was introduced from 1867 to 1949. After it, since the 1950s the following categories can be found: county town, town of county rank, district town, town of district rank. (Beluszky-Győri 2005)

There is not a set limit regarding the number of settlement which can be declared towns. According to the „Magyar Köztársaság Helységnévtára” ('List of Place-names in the Hungarian Republic'), to 1950 50, then till 1990 112, then about two decades later, today 328 towns can be found in our country (http://portal.ksh.hu/pls/portal/cp.helyegnevtar, 2011). The trend to give a town rank is getting bigger. It can be seen exactly that most of the settlements were declared towns after the political transformation. This tendency is still going on after our joining to the EU.

There are several factors which every settlement has to accomplish in order to obtain the town rank. These are the following: density of buildings, number of population, density of population, economical-social structure. These factors are different in a village on the Hungarian Plain, in the agglomeration of Budapest or in a village of the Transdanubian area. Naturally, these places have to prove a higher level of development as compared to the level of their region.

It belongs to the most essential conditions that only the settlement can be a town which has already been ranked as a "nagyközség". Two important factors should be considered, as well: the human one and the time-space relations. Since it is the human factor which is in the centre, the most convenient claims should be realized and maintained. The 
other important component is the time-space relation, which is to say, the age and special location of the given settlement.

The legislative power intended to construct flexible index-numbers which can mean a realizable challenge for all candidate-towns. However, there is only one exception which separates the urban area from the rural one, it is density of population. It was the OECD (Organization for Economic Cooperation and Development) to fix this value as 150 person $/ \mathrm{km}^{2}$. It cannot be accomplished in each settlement; this index-number is 147 person $/ \mathrm{km}^{2}$ in case of Sándorfalva, which is slightly less than the desired number. Besides, the settlement can become a town if its population is over 5.000 people. This index-number, in case of Sándorfalva, outnumbers the fixed value since, even at time of the initiation, it exceeded 8.000. Apart from the index-numbers, the economical-infrastructural level of development, the social-regional roles, traditions, cultural life are all taken into consideration. In addition to the desired level of development, the given place should provide basic and central functions, as well. These two criteria: the level of development and central function are determinant factors. In case of Sándorfalva they can be regarded as satisfactory ones.

Between 1879 and 2005, Sándorfalva induced index-numbers which gave hope to obtain the town rank. Among the settlements of Szeged Small Region Sándorfalva is the second most populated one, after Szeged. Within the county it precedes towns like Kistelek, Mindszent or Mórahalom (Takács 1979).

Before obtaining the town rank, it had to prepared itself to get it which was quite a long process. The „nagyközség" had to realize measures which could ensure its purpose. It was important to increase the population, economical, infrastructural index-numbers. These conditions not only provide better living conditions for the population but also they result in a more attractive image of the small town.

A rural development conception was realized with which they can ensure the use of classification of the competitive town. First of all, it is necessary to find solutions to improve economy. Besides, it is necessary to motivate people to move there. After the "nagyközség" initiated to become a town the number of population grew continuously. The number of people living there has more than doubled and this process is still going on.

Sándorfalva can be considered as a strong settlement from the economical-commercial points of view, it has a large number of shops and a marketplace, too. It clearly shows the importance of the market that a lot of people from the neighboring places go to Sándorfalva to sell and buy things.

The settlement has a nursery school, a kindergarten, a primary school and an evening secondary school. The town attracts students from the neighboring villages (Dóc, Baks, Szatymaz) to go to school there. (Picture 2)

The building is completely suitable for the quality education to obtain competitive knowledge.

The settlement has a strong cultural past due to its famous zitherists. Every year they perform in several programs where the people from the neighboring villages go, too.

The town has 3 surgeries for adults, 1 for children, there is a vet, too and 2 dentists but they receive private patients, as well.

From the 1990s a lot of people from Szeged have chosen the small gardens in Sándorfalva when they wanted to relax. Its traffic is quite heavy due to the SzegedÓpusztaszer-Csongrád-axis.

From the 1980s the village-town flow has changed, and people moved to the villages from the bigger towns. The villages around Szeged increased the most quickly their population: besides settlements Sándorfalva, Deszk, Újszentiván, Zsombó. More and more people moved from Szeged due to the reasonable prices of plots and the favorable transport conditions. In the year of becoming town 10 juvenile fell on 84 elderly which is a special 
starting point to strengthen the social structure of the settlement. Over the years the number of people with university degree has multiplied. The proportion of people with secondary qualification is extremely high.

Picture 2. The renovated and amplified school building in the town centre

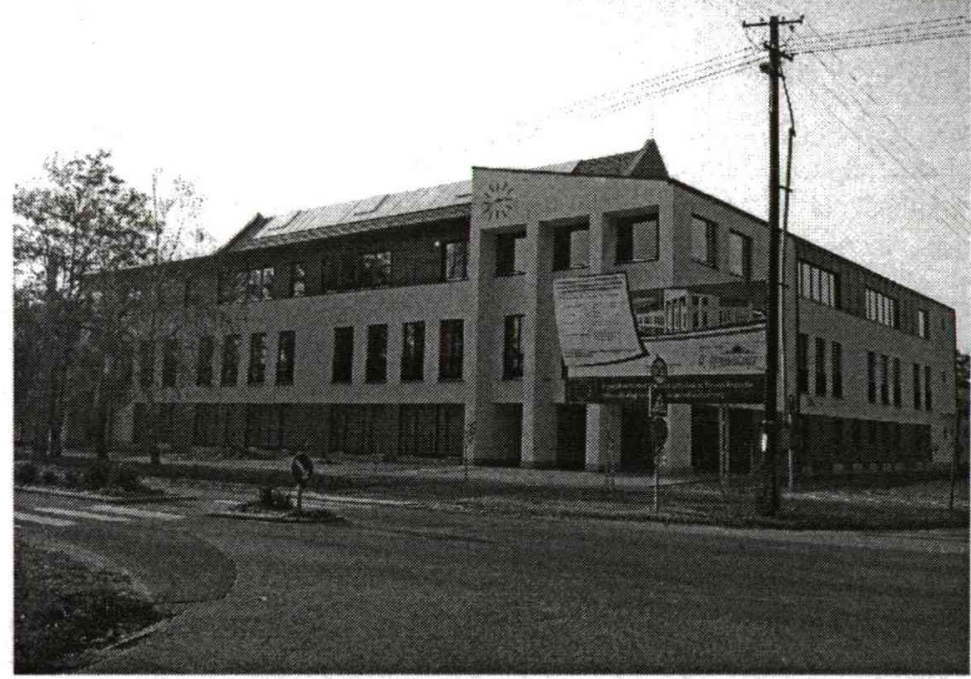

Source: the author's own image, 2011

The majority of employees from Sándorfalva commute between its living and working places. Most of them go to work mainly to Szeged, then to villages Ópusztaszer, Kistelek and Szatymaz. The unemployment rate is under the national average.

After the millennium they did not break with the former ways of living, since in the settlement the agricultural production, cultivation and onion cultivation are all significant. As for animal husbandry, it is typical to rear poultry and pigs. Regarding the industrial production it has hundreds of ventures of different sizes, besides broom manufacturing. It strengthens its regional role that these ventures fulfill the demands of the neighboring settlements, thus they result in an economical increase for the town. It has two rifle clubs and the Szeged Fish Ltd, which deals with fish-breeding, plays an important role in the economical life of the settlement.

Shops, places with commercial and service activities fulfill the demands not only of the people in Sándorfalva but that of the population of the nearby villages, as well. Services of the commercial units in Sándorfalva are utilized by the majority of villages Balástya, Dóc, Szatymaz and the people who have small gardens along the road Szeged-Csongrád. All basic services are available in a suitable level. Commercial supply is of urban level. Regarding its size, the market is of fair-type, $90 \%$ of the sellers and $40 \%$ of the customers come from different places.

The tourism is not really utilized though lots of natural treasures can be found in the settlement and its neighborhood, catering and tourism fall behind the desired level. Its infrastructural development is solved with the exception of the sewage disposal.

The settlement has always been within easy reach but the real change was expected with the construction of the road to connect it with Algyő. The motorway was finished a short time ago so its effect cannot be measured. 
In 1996 the police station of Sándorfalva was established which villages Szatymaz and Dóc belong to. Even the Association of Civil Guards was established in 1995. It shows the regional role of the Association that they can be called even from villages Baks, Dóc, Szatymaz, Szeged and Ópusztaszer, as well.

The Culture Centre organizes different programs for the students, pensioners and for those who want to entertain. In 1999 the culture centre was nominated after the famous zitherist, Budai Sándor, who was born in this town.

\section{DIRECTION OF DEVELOPMENT}

The Pallavicini Plan (2006) is the document of development which determines the main direction of development for the next 10-15 years.

On the basis of its geographical-natural location, Sándorfalva is an attractive place for tourism, apart from this it can utilize the vicinity of Ópusztaszer. The most important conceptions of development are retention of the urban population, establishment of new working places and development of the economical-social structure.

All in all, a conception of town development should be realized which has an effect on all fields of life.

A town lives if stability and development can live together in it. A town can be lived if it has its own history. "Its own history is the plurality of memories and novelties, grandpa's reminiscences and the grandchildren's faces of surprise." (Botka 2011)

Reconstruction of the castle is of that kind which will represent a value of great importance for the town. Due to the work, Pallavicini Castle in the centre is being transformed into a historic and ethnographic museum. It is planned to rebuild the house of the famous zitherist, Budai, Sándor into a Memorial House where there will be an exhibition on the history of the zither which is a unique one in Europe.

In the Széchenyi Court, where a playing ground and a skating-rink can be found, a new community centre is planned to be built with which more space will be gained for the younger ones.

The government of the town has set as an aim that everything should be preserved which is worth and everything should be renewed which is necessary. (Botka 2011)

They consider important to form new plots in the interest to increase the Town's population. As a result, the settlement will be not only more attractive but it promises success for everybody in the long run.

\section{SUMMARY}

We tried to find what requirements the settlement of Sándorfalva had to fulfill in order to obtain the town rank and how it could realize them. It is totally proved that it fulfilled the criteria of the town rank and it has stepped on the road of development.

People living there are satisfied with these results, and they are interested in how this improvement is going on. Keeping the people's demands in consideration, it can result in development which can ensure competitiveness. It was based on the evaluation of the possibilities, elaboration and realization of development conceptions and action plans, together with the image of a livable town. Sándorfalva would like to develop its regional and sub regional role and importance.

Today urbanization is an important phenomenon. Interpersonal relations develop altogether with it. Meanwhile it is necessary to decide between old and new. A new sphere of human life is coming to light in space and time. The main source of this force is tradition. 


\section{BIBLIOGRAPHY}

Beluszky Pál - Győri Róbert (2005): Magyar városhálózat a 20. század elején Dialóg Campus Kiadó, Budapest-Pécs

Botka László (2011): Része lesz az életünknek 2011. 10. 01. Délvilág, 3.p.

Gálné Horváth Ildikó (2010): Some Social Aspects of Boondocks' Life in South-East Hungary int he $21^{\text {st }}$ Century, Management Agricol, seria I, vol. XII(1), Editura Agroprint Timisoara, Romania, 143-148.p.

Granasztói Pál (1984): A tradíció funkciója, építészet, városépítés, társadalom, Akadémiai Kiadó Vélemények, viták a Városépítésröl 1984, Kossuth Kiadó, Budapest, 197.p.

Komor Vilma (szerk.) (1985): A falu, Településpolitika, falufejlesztés, építészet; Budapest 1985, szerk.: Komor Vilma, Mezőgazdasági és Élelmezésügyi Minisztérium Információs Központja, Budapest, 504. p.

Magyar Köztársaság Helységnévtára http://portal.ksh.hu/pls/portal/cp.helysegnevtar 2011.10.22.

Perczel Károly (1984): Az ismeretlen OTK és a településhálózat fejlesztés újraértékelése; vélemények, viták a városépítésről, Kossuth Kiadó, Budapest, 76.p.

Takács Máté (1979): Szeged és környékének kölcsönhatása - „munkamegosztás” a települések között, Csongrád Megyei Szemle, Szeged, 35.p. 